\title{
Religious Instruction for Students with Autism in an Inclusive Primary School
}

\author{
Hakiman Hakiman* \\ Universitas Islam Negeri Raden Mas Said, Surakarta, Central Java Province, Indonesia \\ https://orcid.org/0000-0003-4241-9136 \\ Bambang Sumardjoko and Waston Waston \\ Universitas Muhammadiyah, Surakarta, Central Java Province, Indonesia \\ https://orcid.org/0000-0002-5138-0467 \\ https://orcid.org/0000-0001-8495-9822
}

\begin{abstract}
This study describes religious instruction for students with autism conveyed by classroom teachers, Islamic Education teachers, shadow teachers, and parents through a mentoring program in school and family environments. This qualitative phenomenological study was carried out in an inclusive primary school in Surakarta, Central Java, Indonesia. Five students with autism and their parents, five classroom teachers, five shadow teachers, and three Islamic Education teachers were involved in this study. Data were collected through in-depth interviews, participant observation, documentation, and focus group discussions (FGDs). They were analyzed using interpretative phenomenological analysis and an interactive approach. This study reveals that optimal outcomes of religious instruction entail collaboration among Islamic Education teachers, classroom teachers, shadow teachers, and parents with the assistance of psychologists, counsellors, therapists, pedagogues, and school policies. Such collaboration is particularly required in the implementation of an adaptive curriculum, lesson plans, learning implementation, evaluation, mentoring and the habituation of worship. The modification of learning methods, media, and evaluation is also required.
\end{abstract}

Keywords: religious instruction; students with autism; inclusive education; phenomenology

\section{Introduction}

Learning is a lifetime activity carried out by humans as an attempt to achieve human perfection. In this context, perfection is indicated by critical thinking,

\footnotetext{
*Corresponding author: Hakiman Hakiman, hakiman.iman@gmail.com
} 
physical intelligence, and spiritual intelligence. As stipulated by the law, the purpose of national education is to cultivate the potential of students to possess religious and spiritual strength, self-control, personality, intelligence, a noble character, and the skills required by individuals, society, the nation and the state.

The personality of Muslims is represented by the extent to which they carry out Allah's command and practice worship, one of which is Salat as an obligatory prayer for Muslims. Salat represents one's submission to the Creator, a form of obedience and piety shown by the humble servants of Allah. Furthermore, Chapter II Article 3 of Act Number 20 of 2003 stipulates that the National Education System generates students with faith in and reverence of God Almighty (Republik Indonesia, 2013). The Muslims express their faith and piety through the five daily prayers.

Islamic Education is listed as a compulsory subject at every level of education. This subject comprises Qur'anic studies, Aqeedah, Morals, Worship, and History of Islam. In Indonesia, religious instruction must be delivered to students regardless of their background, including students with special needs or autism. Religious instruction fulfils a spiritual need for children with special needs as spirituality is an essential element for their lives, while spiritual practices bring a sense of well-being and strength to those with disabilities (Poston \& Turnbull, 2004). The provision of religious instruction allows Muslim students, both normal and those with special needs, to participate in religious beliefs and practices (Brooke \& Smith, 2009). However, an inclusive pedagogy approach to eliminating discrimination among students (Raguindin \& Ping, 2020) is required. It can be done by providing a platform to support the needs of autistic students.

Despite their weaknesses and strengths, students with autism are entitled to proper education, including religious instruction. In Bakker et al., (2019) the American Psychiatric Association explains that autism is a neurodevelopmental disorder characterized by qualitative impairments in social interaction, social communication, and repetitive and stereotyped patterns in behaviours. According to Sha'arani and Tahar (2017), autistic children have some social problems, including weakness in bilateral interactions, communication, and imagination. Individuals with autism tend to be aggressive, hyperactive, or hypoactive (Usop \& Lilik, 2017). According to Heward et al., (2013), children with autism spectrum disorder (ASD) show impairment in communication skills and social interactions and engage in repetitive and stereotyped behaviours. Therefore, in the educational process, they need special support and treatment.

In a study, Hanum (2012) reveals the lack of references to Islamic Education for students with special needs, which becomes an obstacle for Islamic Education teachers. Meanwhile, there is a need for a distinctive Islamic Education curriculum for these students (Zulaikhah et al., 2020). This requires the government's support to assist inclusive schools, one way of which is by providing guidelines for Islamic Education or religious instruction for students 
with autism (Arlinwibowo et al., 2020). In addition, the provision of internal training and professional development regarding the strategies for teaching students with learning difficulties can be a part of the government's policy (Matolo \& Rambuda, 2021).

An inclusive school is a representative place for providing religious education for students with autism. According to the Committee on Educational Interventions for Children with Autism (2001), education for children with autism entails the access to an educational program that best meets their special needs. For Muslim children with autism, such knowledge and skills involve independence and the ability to practice worship. Schaap-Jonker et al., (2013) suggest that religion or religiosity is fundamental for children with autism, and serves as a clinical medium for them. There is a high level of expectation that worship education delivered to students with autism in inclusive schools will have a positive impact on them.

According to Drame \& Kamphoff (2015), educating children with special needs under inclusive education involves being able to improve their academic achievement, skills, peer acceptance, self-esteem, and friendship networks with lifelong benefits. Special education acknowledges and accepts a greater plurality of perspectives about the nature of disability (Baglieri et al., 2011). The ultimate goal of inclusive education for children with special needs is to support and teach them to carry out daily activities independently (Rahman \& Dahlan, 2015), including performing worship.

As suggested by Asiyah (2018), inclusive schools offer adaptive education programs and special services for students with special needs, particularly to optimize student satisfaction and learning outcomes. Koh \& Shin (2017) suggest that inclusive education becomes a preferred educational service for children with special needs. Religious instruction delivered by Islamic Education teachers, shadow teachers, and parents is deemed important for fostering knowledge, skills, and habituation for students with autism. In addition, the implementation of religious instruction for these students requires learning modification and collaboration among Islamic Education teachers, classroom teachers, shadow teachers, parents, and experts in order to support its effectiveness.

This study provides important information on how religious instruction is delivered to students with autism by using an inclusive pedagogic approach, namely by involving an inclusive team that consists of psychologists, counsellors, and pedagogues, and by initiating collaboration between multiple teachers and parents in the planning, implementing, and evaluating of learning. This study provides input for practitioners, school administrators, and teachers, particularly in providing religious instruction for students with autism.

\section{Literature Review}

Worship is also known as ibadah (عبادة), an Arabic word meaning 'service' or 'servitude'. In Indonesian terminology as stated in Kamus Besar Bahasa Indonesia 
(KBBI), worship means i) an act or declaration of devotion to God based on religious teaching, ii) the physical and spiritual efforts based on religious teachings that must be performed by the adherents, and iii) religious rituals. Carrying out worship, such as daily prayers, is perceived by Muslims as a command from God that must be carried out as ordered in the Qur'an (Tim Badan Pengembangan dan Pembinaan Bahasa, 2016). According to Rasyid (2002), prayer is a practice of worship composed of prescribed repetitive actions and recitations, started with Takbir and ended with Taslim.

Every Muslim must understand and have skills in praying regardless of their background. Despite their limitations, children with autism are also required to perform prayers. Several jurists and Islamic scholars have discussed the obligation of mandatory prayers for children with autism (Mian, 2012). Many studies have also discussed teaching strategies for students with autism, including those of Puspitaningtyas \& Pratiwi (2018) Lal \& Ganesan (2011), and Sha'arani \& Tahar (2017). These studies, however, discussed the teaching methods of Islamic Education in a general context. Meanwhile, previous studies that focus on the methods for conveying religious instruction, including Sugiarti et al., (2019), Abas et al., (2015), and Rahmawati (2018), have not addressed the special needs of students with autism. These studies only involved Islamic Education teachers instead of all related teachers such as classroom teachers and shadow teachers.

Special services are required to convey proper religious education for students with autism. In Islam, the provision of educational institutions, programs, and self-development for children with special needs is a shared responsibility for all members of society (Al-Aoufi et al., 2012). It emphasizes that children with special needs require special education services. According to Morad et al. (2001), caring for individuals with special needs is the duty of every Muslim and every Islamic State and society, which is in accordance with the Islamic humanistic philosophy encompassed in the Qur'an and Islamic theology.

Inclusive schools are the best option for students with autism to be taught and to participate in worship practices along with their peers. Villa \& Thausand (2005) highlight the capacity of inclusive education in embracing all groups and ensuring the rights of all students in society. Breakey (2006) proposed the following requirements of inclusive education: i) classroom management that consists of the seating arrangements in classroom, lighting, and a constructive environment; ii) communication skills that involve the use of a clear voice and being concise, the avoidance of euphemisms and physical touch, the use of verbal and visual instructions supported by visual media, and memory assistance; and iii) the implementation of suitable learning methods, for example visual and kinaesthetic methods supported by videos, games, simulations, pictures and diagrams, social stories, and cartoons.

According to Breakey (2006), the Treatment and Education of Autistic and Related Communication Handicapped Children (TEACCH) is the most widely used approach to treat children with autism. The National Autistic Society (2020) 
explains the principles of TEACCH, as i) improving adaptation through modified education and learning environment, ii) collaborating with parents and professionals, iii) determining individual needs using an educational assessment program based on individual abilities, iv) structured teaching, v) improving skills through training for parents and educators, vi) cognitive and behavioural therapy, and vii) generalist training for all professionals, not just psychologists or therapists, involved in the TEACCH system.

The roles of shadow teachers are integral to the education of students with autism. According to Iswandia et al., (2017), these roles are i) to collaborate with classroom teachers in preparing learning activities; ii) to assist children with special needs by providing concise and clear instructions to complete their tasks; iii) to socialize and select peers for children in performing various activities; iv) to direct children with special needs in the habituation of positive routine activities; v) to arrange both indoor and outdoor activities for children with special needs; vi) to give rewards and punishment for children with special needs; vii) to minimize the failure of children with special needs; and viii) to deliver fun teaching to children with special needs.

Furthermore, parents make a major contribution to the milestones attained by students with autism. Gunarsa (2003) claims that parents' support and motivation will accelerate a child's recovery from autism. McDonald (2014) suggests four activities initiated by parents for children with autism, namely i) endeavouring to seek a diagnosis for their children; ii) endeavouring to find, obtain, maintain, and provide appropriate education for their children; iii) finding solutions to resolve the constant difficulties associated with their children's education; and iv) planning for the future of their children. Worship education for students with autism can be carried out comprehensively by classroom teachers, Islamic Education teachers, shadow teachers, and parents. The adaptive curriculum is specially devised according to the needs of students with autism.

Previous articles could be relevant to the topic discussed in the present study; however, this study attempts to specify the discussion about religious instruction for students with autism from the perspective of teachers, parents, and experts. In addition, this study proposes a new approach to deliver religious instruction to these students in inclusive schools, namely through collaboration and modification in learning outcomes, learning processes, and mentoring.

\section{Research Methods}

This study is qualitative research using a phenomenological approach in which researchers attempt to understand the substantial meaning of events and experiences by conducting direct investigations on individuals involved in worship education. Hansen (1983) and Watson \& Thompson (2016) have suggested the feasibility of the phenomenological approach for studies on religious education in schools. The present study was conducted at the Islamic Elementary School Surakarta, the first school in Central Java, Indonesia to offer an inclusive education. It involved five students with autism and their parents, 
three Islamic Education teachers, and five shadow teachers. The description of research participants is presented in Table 1.

Table 1: Research subjects

\begin{tabular}{|c|c|}
\hline Code & Status \\
\hline MR & Student of Class 2A \\
\hline FR & Student of Class 2 B \\
\hline MI & Student of Class 3 \\
\hline $\mathrm{KN}$ & Student of Class 4 \\
\hline MT & Student of Class 5 \\
\hline $\mathrm{ZN}$ & Shadow teacher of Student KN \\
\hline NC & Shadow teacher of Student MR \\
\hline LL & Shadow teacher of Student MI \\
\hline RB & Shadow teacher of Student MT \\
\hline FT & Shadow teacher of Student FR \\
\hline $\mathrm{AF}$ & Islamic education teacher of Class $2 \mathrm{~A}$ and $2 \mathrm{~B}$ \\
\hline $\mathrm{FH}$ & Islamic education teacher of Class 3 \\
\hline NR & Islamic education teacher of Class 4 and 5 \\
\hline SR & Classroom teacher of Class 2 \\
\hline $\mathrm{FH}$ & Classroom teacher of Class 3 \\
\hline AT & Classroom teacher of Class 4 \\
\hline $\mathrm{YN}$ & Classroom teacher of Class 5 \\
\hline $\mathrm{TN}$ & Parent of Student KN \\
\hline $\mathrm{AP}$ & Parent of Student MR \\
\hline SA & Parent of Student MI \\
\hline DJ & Parent of Student FR \\
\hline $\mathrm{AC}$ & Parent of Student MT \\
\hline
\end{tabular}

In addition to the primary research subjects in Table 1, this study also involved other respondents such as school principal, an inclusive education team, and other academic staff.

The data were collected using an in-depth interview technique. Subsequently, they were analyzed using the interpretative phenomenological analysis [IPA] proposed by Smith et al., (2009), namely i) reading and re-reading; ii) initially making notes and becoming familiar with the text; iii) developing emergent themes; iv) searching for connections across emergent themes; v) moving to the next cases; and vi) looking for patterns across cases. Observations, documentation, and FGDs were also carried out to obtain data. Subsequently, a triangulation technique was used to validate the data. As for the data analysis technique, the interactive analysis developed by Miles et al., (2014) was conducted. It involved data collection, data reduction, data display, and 
conclusion drawing. This study was conducted from July 2019 to December 2020.

\section{Results and Discussion}

In Indonesia, the world's largest Muslim country, religious instruction is a compulsory subject that must be delivered to every Muslim child. Salat prayers are the most fundamental worship for Muslims, and every child must know, understand, and practice these prayers. Accepting and practicing worship based on one's belief are among the core competencies for students that are stated in the Islamic Education Curriculum issued by the Ministry of Religion of the Republic of Indonesia (Kementerian Agama Republik Indonesia, 2019). In inclusive Islamic schools, including Elementary School Surakarta, religious instruction is one of the prioritized programs. This school is committed to ensuring that all students perform and are accustomed to praying five times a day. Religious instruction is the commitment of the school community and worship is the noble goal of the school.

Religious education is delivered to students with autism through learning activities and mentoring. It entails the collaboration among the classroom teacher, Islamic Education teacher, shadow teacher, and parent. However, before the implementation of religious education, an individual assessment is conducted by an inclusive education team. This team consists of counsellors, psychologists, pedagogues, and therapists. Principally, assessment is done to identify the condition of students before they carry out learning activities and it is the responsibility of Muslim teachers (Hakiman et al., 2020). Religious instruction for students with autism in inclusive Islamic schools is carried out through classroom learning, mentoring inside and outside the classroom by shadow teachers, and learning and mentoring by parents at home. Worship education for elementary school students is mainly concerned with purification or tahära and prayer.

\subsection{Religious Instruction for Students with Autism}

Religious instruction for students with autism in schools is carried out by Islamic Education teachers, classroom teachers, and shadow teachers. From the FGD with the principal as policymaker, the inclusive education team, classroom teachers, and shadow teachers, religious instruction can be summarized as being carried out through learning activities, mentoring, and habituation. Religious instruction also involves the participation of the inclusive education team and parents. The role of the inclusive education team (counsellors, pedagogues, and psychologists) in the development of religious instruction is significant. Furthermore, learning actions are devised according to assessments, observations, and consultations with the parents and the inclusive education team. The results become the basis for teachers in planning, implementing, and evaluating the results of worship learning activities. The learning outcomes are based on the needs of students instead of the needs of teachers. Therefore, individual learning is regarded as a suitable basis for learning for children with special needs or autism. The modification of learning strategies and objectives or outcomes is a part of multicultural learning. 
The implementation of religious instruction for students with autism uses an adaptive curriculum, also known as an accommodative curriculum. This curriculum is tailored to the unique characteristics of these students (Leytham et al., 2020). In the accommodative curriculum, teachers modify instructional strategies, learning media, assessments, and relevant activities based on student needs. It confirms the views of Kustawan (2013) on the use of an adaptive curriculum to optimize the learning process in inclusive schools. Worship curricula and learning are designated to facilitate students with autism to enhance their self-reliance in worship. Onwumere et al., (2020) support an independent curriculum to improve student skills for their future needs. Religious instruction, however, are the needs of autistic Muslim students as religious human beings.

Religious instruction for students with autism is complemented by an inclusive education program and an individualized education program [IEP]. In religious instruction, the IEP is vital to ensure the effectiveness of learning. The significance of an individualized program for the successful learning process is also suggested by Zee \& Koomen (2016) and Love et al., (2020) Moreover, the IEP is devised according to the needs of each student (Zulyan et al., 2020). It covers the targets to be achieved in each worship lesson, which are described comprehensively. As far as the learning outcomes are concerned, it is expected that students should be able to perform the functions of worship (such as ablutions and prayers) correctly and in an orderly fashion. The goals of children's education are clearly defined in individual learning programs. Briefly, learning objectives are clearly illustrated in the IEP (Fiorenzo \& Barbara, 2020).

The lesson plan for students with autism comprises three components, namely an inclusive education program, an individualized education program/IEP, and a special education program. The inclusive education program is devised and implemented by the Islamic Education teacher in the conventional classroom. On the other hand, the individualized education program/IEP is devised by shadow teacher and classroom teacher and implemented by shadow teacher in the classroom; while the special education program is devised by the shadow teacher based on the inputs from the subject teacher, classroom teacher, parents, and inclusive education team. Furthermore, it is implemented by the shadow teacher during mentoring and learning in school. The composition of the inclusive education program and IEP is based on the modified syllabus, while the special education program is mostly based on the inputs from the shadow teacher and the parents.

The IEP of religious instruction is tailored according to the assessment, observations, subject matter, and abilities of each student. During the preparation of the IEP, the shadow teacher will observe and communicate with parents in order to attain the expected outcomes and fulfil the needs of each student. According to Richardson-gibbs et al., (2012), learning modification is required, namely by adjusting the regular material to suit the needs of students with autism. 
The implementation of worship education in inclusive schools is carried out by the Islamic Education teacher, classroom teacher, and shadow teacher. The involvement of shadow teachers and parents in preparing lesson plans is a hallmark of inclusive education. Moreover, inclusive education requires the collaboration of teachers in the classroom (Carrington et al., 2020). While collaboration is essential in teaching students with autism, Van Der Steen et al. (2020) emphasize the significant role of professionals.

The use of visual learning media such as PowerPoint presentations, videos, and images, is also useful to engage the attention of students with autism. Merdan \& Ozcan (2020) and Wright et al., (2020) report the effectiveness of video as a medium in teaching these students. The Islamic Education teachers modify the steps of worship (ablution and prayer) into colourful and large-sized images to make the concept more comprehensible for students. The teachers also hang the images on the walls of classrooms and mosques to help students with autism recall and practice worship. In addition to videos, virtual reality images are a useful learning medium (Cihak et al., 2016).

Ablutions comprise an orderly set of movements consisting of being clean by washing the face, washing hands, wiping the head/hair, and washing the feet. Therefore, simulation and practice are considered to be suitable learning methods. Likewise, prayers comprise several movements, beginning with Takbir and ending with Taslim. A direct visual model, such as teacher demonstration, is more efficient than an auditory model since it better enables students with autism to memorize the steps. Owing to problems in receiving verbal instructions, the audio model is less efficient for students with autism.

In carrying out learning activities, the Islamic Education teacher is assisted by the classroom teacher with particular role. The classroom teacher serves to set up the class during teaching-learning activities and assists students with autism to stay focused during the class. Meanwhile, shadow teachers participate by sitting next to these students, directing them, and repeating the material to each individual. Shadow teachers provide individual repetitions both inside and outside the classroom for the enrichment of worship education.

The Islamic Education teacher demonstrates the worship movements of ablutions and prayers, while the students imitate the movements with the assistance of the shadow teacher. The shadow teacher physically guides the students, while classroom teacher manages and helps provide instructions for the students. Maftuhin \& Fuad (2018) suggest that the learning strategies for students with special needs should involve various approaches. Therefore the creativity and skills of teachers are very important in providing religious instruction to students with autism (Kistoro et al., 2020).

In addition to the learning activities in a conventional class and beyond, the school also encourages students to perform ablutions, attend congregational prayers, and perform the Duha prayer to improve student understanding, skills and experiences in worship activities. Congregational prayer is a strategy in 
worship education. According to Syamsuri et al., (2021), habituation is a learning strategy used by the Islamic Education teachers for students with special needs. Similarly, Angdreani et al., (2020) assert that habituation is an effective method for instilling religious values in elementary school students.

Evaluation of religious instruction for students with autism is emphasized as a continuous process or an ongoing evaluation (Anshar et al., 2020). In addition to the evaluation process, student learning and performance are also evaluated through examinations. Worship is a skill that students with autism need to have. Therefore, assessment is done during the practices in the classroom as well as the actual implementation of worship at school. Practical evaluation involves the active participation of students with autism in the classroom (Sparapani et al., 2016).

Furthermore, student knowledge about worship is evaluated through a final examination set by the shadow teacher with the approval of the Islamic Education teacher and classroom teacher. The questions are presented in images, such as sorting out images of ablutions and prayers. According to Spector (2011), learning evaluation must be supported by visual media, including images. While learning evaluation highlights the characteristics of each student with autism, it should focus on the student's needs. Oktari et al., (2020) suggest that the evaluation of Islamic Education must be adjusted to each student's special circumstances.

The evaluation of students' skills carried out by teachers during the learning process and worship activities at school is a measurable evaluation. It means that students' performance can be continuously improved with the assistance of shadow teachers. Moreover, regular information from parents who monitor their children while carrying out worship at home is valuable in the evaluation process. Essentially, in learning evaluation for students with autism there is more emphasis on direct observation or authentic assessment, namely how they perform worship. Authentic assessment is stipulated in the Education and Culture Minister Regulation Number 104 of 2014 as the main approach for assessing learning outcomes (Republik Indonesia, 2014). In the context of worship education, such assessment is conducted by observing students in practicing ablutions and prayers.

\subsection{Worship Mentoring for Students with Autism}

The shadow teachers have a major role in the effectiveness of worship instruction for students with autism, particularly in the classroom. The presence of shadow teachers enables the optimization of learning interactions (Rämä et al., 2020). They provide individual repetition of material to the students with short and clear instructions during the class (Iswandia et al., 2017), and help them stay focused (Nur'aini et al., 2014). Good communication is a fundamental factor in teaching Islamic Education (Bosra et al., 2020).

Shadow teachers have multiple roles, namely as teacher, mentor, trainer, and parent in school. Shadow teachers also act as a bridge between students with autism, and their peers and the environment. Kustawan (2013) emphasizes the 
role of shadow teachers in the curriculum development. It is in line with Article 41 of the Government Regulation Number 19 of 2005 of the National Education Standards Republik Indonesia (2005) that every education unit that carries out inclusive education must have professional educational personnel capable of organizing learning for students with special needs.

Shadow teachers are required to provide teaching, mentoring, coaching, and religious guidance for students with autism. The Elementary School mandates the shadow teachers to provide worship assistance to students with autism so that the students can worship independently. The collaboration between shadow teachers and the inclusive education team is invaluable in enriching the knowledge about inclusive education for these students. They can exchange experiences and share their skills regarding the treatment of these children.

During the conventional class, shadow teachers are required to sit next to students with autism, assist and direct them to pay attention to PowerPoint or videos presented at the front of the class. Shadow teachers assist these students by holding their hands to imitate ablution or prayer movements and giving short and clear instructions related to verbal information. They perform individual repetitions both in inside and outside the classroom. They also bring modified learning media. Among the duties and roles of the shadow teachers, according to Iswandia et al., (2017), is providing short and clear instructions for completing their tasks to students with autism.

The shadow teachers assist students with autism who experience difficulties in learning by offering repetition, enrichment, or remedial tasks. They also guide the students to practice worship on an ongoing basis and record notes for the follow-up mentoring activities. Regarding worship education, students with autism require a particular form of assisted learning or heilpedagogy, which is necessary considering that students with autism face challenges in learning. According to Kok et al., (2014), teaching students with autism requires assisted teaching, namely the assistance from shadow teachers.

Mentoring is carried out by shadow teacher by sitting next to students with autism to direct and help them concentrate on lessons. It is confirmed by Nur'aini et al., (2014) that shadow teachers assist the students to focus and participate in the class.

The shadow teachers assist students with autism in the school environment. In teaching students how to perform ablutions, the shadow teacher promotes habituation by escorting them to the mosque to perform their ablutions before praying. In addition to using learning media such as images and videos, the shadow teacher also teaches the theory and practice of ablutions that cover practice methods, practice with instructions, and independent practice. Before the practice, the shadow teacher instructs students with autism to observe peers who perform their ablutions appropriately and then instructs them to imitate the steps. For students with autism, mentoring is carried out comprehensively, not only during the conventional class, but also outside the class. While the students 
are at school, the classroom teacher and shadow teacher are required to provide assistance to them. Shadow teachers are the spearhead of inclusive schools as the success of learning mainly depends on them. Hamid et al., (2020) contend that shadow teachers have a key role in inclusive schools in the development of the academic and social abilities of students with special needs.

\subsection{The Role of Parents in Worship Education}

Muslim parents expect their children to live according to Islamic values, and to be independent in carrying out the five daily prayers. McDonald (2014) suggests that most parents attempt to provide the best education for the future of their children.

Elementary School Surakarta requires parents' participation in several school activities. The formulation of the IEP, for example, is a medium of communication between schools and parents, a medium for dialogue between schools and parents, and a medium for parental involvement in arranging educational programs for their children. Consultation services have been suggested by Azad et al., (2020) as a means to improve communication between teachers and parents.

Schools and parents have the same vision in providing religious education for students with autism. Therefore, there should be a synchronization of worship programs held at schools and at home. The involvement of parents in religious instruction will support the learning achievement of students with autism (Jauhari \& Rafikayati, 2018). Parents are involved in planning and implementing worship education as they act as informants, partners, observers, and evaluators. Parents also provide information to the shadow teacher about the condition and the needs of their children. Parents further become school partners and teachers in formulating mentoring programs, and also partners in providing learning and worship assistance to students with autism. In addition, parents are the observers at home by communicating and interacting with these students. In the process, parents will determine the needs and development of their children.

Mentoring is carried out by shadow teachers at school and home. Therefore, it needs cooperation with parents that will enable parents to observe the child's progress in practicing worship. Parents simultaneously, continuously, and naturally monitor and supervise the development of their children in performing worship, making them evaluators at the same time. The participation of parents in providing religious instruction at home includes the repetition of worship lessons conducted at school. Moreover, parents help shadow teachers in delivering religious instruction by playing worship-related videos on YouTube.

The implementation of religious instruction at home is done by accompanying children in memorizing ablution and prayer movements, dua, and recitation during prayers, the shortest letters in the Qur'an, and dua for parents. Moreover, flexible learning time allows the children to learn whenever it is convenient and when they show enthusiasm for it. There is no restriction of a learning time and place. Learning while playing is a strategy used by parents at home. 
Using rewards such as appreciation, praise, and gifts (favorite foods and toys) is among the learning strategies of parents. The verbal and non-verbal advice given by parents will have a positive impact on their children. Their support is the motivation for children to learn. It has been stated by Sarafino \& Smith (2011) that parents' support comprises rewards, emotional appreciation, and physical and emotional support as a member of family or community.

At home, parents create fun learning by providing learning resources such as pictures, picture books, and puzzles of ablution and prayer movements to engage and interest children. One of the characteristics of children with autism is their fondness for visual media; hence parents can use visual learning facilities such as Islamic videos on YouTube. In addition to improving their visual skills, parents can hang various illustrations such as recitations in daily prayers, $d u a$ before entering the toilet, and $d u a$ before and after ablutions, on the walls or doors. For families with children with autism, visual media is a valuable tool. It has been suggested by Rutherford et al., (2020) that it stimulates children with autism to carry out independent learning.

The involvement of parents in worship education entails their wholehearted guidance in mentoring children for performing ablutions, praying independently, and encouraging congregational prayers at home and a nearby mosque. With stereotyped limitations of children with autism, parents attempt to provide guidance and direction to children to pray. Nevertheless, this finding is contrary to that of Afrionita (2014) who revealed that parents of children with special needs tend to practice permissive indulgent parenting, perceiving that praying is not a family obligation. Parents can provide guidance to their children by reminding them of prayer times and providing guidance in their ablutions and prayers. Guidance is carried out continuously until the child is able to perform ablutions and pray independently.

Parents instil the habituation of prayer by instructing, guiding, and observing children while praying, reminding children of the time of prayer, monitoring and supervising children while praying, correcting inappropriate movements, and providing guidance on how to perform prayers correctly and to memorize them. The exemplariness and habituation of parents in carrying out their prayers are the main factors in instilling worship in children with autism. Through the process of guidance, training, and habituation of prayers at home, students with autism are able to pray independently at home until ultimately, they can be disciplined and punctual in carrying out their prayers. Habituation also involves parents' invitation to attend congregational prayers in the mosque with the expectation that children with autism will pray diligently alongside their peers in the congregation. It is exhilarating for parents to see their children attending the mosque.

Students with autism can attend prayers at the mosque together with peers. Congregational prayers at the mosque are also a means of interaction and socialization of children with autism, particularly with peers. They can initiate interaction with their peers and the surrounding community through their 
participation in spiritual activities. It is suggested by Carter (2013) that one of the important aspects in the lives of children with autism is that they can socialize with other people in spiritual and religious activities.

Praying in the congregation at the mosque is an experience as well as a social engagement for students with autism. Prayers are the spiritual activities that will comfort them. Poston \& Turnbull (2004) suggested that religious education is the most fundamental aspect in the lives of children with special needs because spiritual activities bring a sense of wellbeing and strength to them. Worship activities both at school and home are beneficial for students with autism, both psychologically and socially.

It is suggested that prayers can be one of the strategies for parents to adopt to reduce anxiety in children with autism. Prayer can be a solution for the anxiety experienced by children with autism (Adams et al., 2019). The habituation of prayers by parents can be a strategy to cope with this issue. Generally, parents reduce the anxiety experienced by children with autism by creating a quiet, safe, private zone, and by eliminating any potential triggers.

Intensive communication between teachers and parents will enrich the knowledge in the management of students with autism. According to Vassallo et al., (2020), it strengthens the positive outcome of the collaboration between school and family. Parents have an important role in the success of religious education.

\section{Conclusions and Implications}

Religious instruction for students with autism is carried out by prioritizing diversity and respect for all students. Worship education for these students is carried out based on adaptive learning through the modification of learning outcomes, instructional methods, learning media, and the evaluation process. The learning process emphasizes the collaboration between the Islamic Education teacher, classroom teachers, and shadow teachers. Mentoring is done by shadow teachers both at school and at home. For students with autism, mentoring implements the individualized education program [IEP] devised by teachers, an inclusive education team, and parents. Parents play a key role in children's religious education through the habituation of worship at home. Moreover, they can guide and accompany their children while praying at the mosque.

The present study emphasizes the importance of special education for students with autism, which differs from that of students in general. Despite the limitations in time and research subjects, this study proposes collaboration among teachers, policymakers, and parents, as well as the modification of learning strategies to support religious instruction for students with autism. Innovation and creativity initiated by the school (i.e., policymakers, classroom teachers, Islamic Education teachers, shadow teachers, an inclusive education team, and parents) is required in providing religious education for students with autism. 
Furthermore, this study recommends the necessity of providing a guideline for religious education curricula and modules as references for inclusive schools in delivering worship education to students with autism. Principally, the provision of education for students does not necessarily only involve direct parties such as teachers, therapists, counsellors, pedagogues, psychologists and parents, but also religious leaders to provide more comprehensive knowledge. Finally, considering the increasing number of inclusive schools in Indonesia it is important to prepare prospective Islamic Education teachers who understand the characteristics of children with special needs. Further research using the case-study approach to obtain in-depth information about inclusive education for students with autism is required.

\section{References}

Abas, Othman, H., \& Daud. (2015). Islamic Studies for Disabled: Teaching Salat for Autism using Apps. Oasis International Conference on Islamic Education (OICIE2014). https://www.academia.edu/24970121

Adams, D., Young, K., Simpson, K., \& Keen, D. (2019). Parent descriptions of the presentation and management of anxiousness in children on the autism spectrum. Autism, 23(4), 980-992. https://doi.org/10.1177/1362361318794031

Afrionita, C. W. (2014). Pola Asuh Keluarga dalam Pelaksanaan Shalat Anak Tunagrahita ringan(Study Deskriptif Kualitatif di Banu Aran Padang) [Parenting styles in the practice of prayers for children with mild intellectual disability (A qualitative descriptive study in Banu Aran Padang)]. Jurnal Pendidikan Khusus, 3(3), 394-406. http:// ejournal.unp.ac.id/index.php/jupekhu

Al-Aoufi, H., Al-Zyoud, N., \& Shahminan, N. (2012). Islam and the cultural conceptualisation of disability. International Journal of Adolescence and Youth, 17(4), 205-219. https:// doi.org/10.1080/02673843.2011.649565

Angdreani, V., Warsah, I., \& Karolina, A. (2020). Implementasi metode pembiasaan: upaya penanaman nilai-nilai islami siswa SDN 08 Rejang Lebong [Habituation method: Technique to instill Islamic values in students of SDN 08 Rejang Lebong]. Jurnal Iain Bengkulu, 19(1), 1-21. http:// ejournal.iainbengkulu.ac.id/index.php/attalim/\%0AImplementasi

Anshar, M., Ismail, I., Zakariyah, A., Alim, S., \& Adam, A. (2020). Evaluasi Pembelajaran Mapel Fiqih Bagi Anak Berkebutuhan Khusus di MTs Wachid Hasyim Surabaya [Islamic Jurisprudence Evaluation for Children with Special Needs in MTs Wachid Hasyim Surabaya]. Belajea; Jurnal Pendidikan Islam, 5(2), 359. https:// doi.org/10.29240/ belajea.v5i2.1723

Arlinwibowo, J., Retnawati, H., Kartowagiran, B., \& Mustaqim, Y. (2020). Inclusion Schools in the Daerah Istimewa Yogyakarta Province, Indonesia: Regulations, Facilities and Aspirations of Teachers. International Journal of Early Childhood Special Education, 13(1), 09-19. https://doi.org/10.9756/int-jecse/v13i1.211002

Asiyah, D. (2018). Dampak Pola Pembelajaran Sekolah Inklusi terhadap Anak Berkebutuhan Khusus [The influence of inclusive education strategy on children with special needs]. Prophetic, 1(01), 69-82. http://www.syekhnurjati.ac.id/jurnal/index.php/prophetic/article/view/348 0

Azad, G. F., Marcus, S. C., \& Mandell, D. S. (2020). Partners in School: Optimizing Communication between Parents and Teachers of Children with Autism Spectrum Disorder. Journal of Educational and Psychological Consultation, 00(00), 125. https:// doi.org/10.1080/10474412.2020.1830100

Baglieri, S., Valle, J., Connor, D., \& Gallagher, D. (2011). the need for a Plurality of 
perspectives on disability. Journal Remedial and Special Education, 32(1), 267-278. https://doi.org/10.1177/0741932510362200

Bakker, T., Krabbendam, L., Bhulai, S., \& Begeer, S. (2019). Background and enrollment characteristics of students with autism in higher education. Research in Autism Spectrum Disorders, 67(July), 101424. https://doi.org/10.1016/j.rasd.2019.101424

Bosra, M. B., Adi, H. C., \& Syawaliani, G. A. (2020). Teacher's Communication Model in Learning Islamic Education for Autism Children. Al-Ta Lim Journal, 27(3), 306317. https://doi.org/10.15548/jt.v27i3.636

Breakey, C. (2006). The Autism Spectrum and Further Education, A Guide to Good Practice. Jessica Kingsley Publishers. https://www.amazon.co.uk/Autism-SpectrumFurther-Education-Practice/dp/1843103826

Brooke, B. A., \& Smith, D. J. (2009). Multiculturalism, religion, and disability: Implications for special education practitioners. Education and Training in Developmental Disabilities, 44(3), 295-303. https://doi.org/https://doi.org/10.1177/074193251036220

Carrington, S., Saggers, B., Webster, A., Harper-Hill, K., \& Nickerson, J. (2020). What Universal Design for Learning principles, guidelines, and checkpoints are evident in educators' descriptions of their practice when supporting students on the autism spectrum? International Journal of Educational Research, 102(December 2019), 101583. https:// doi.org/10.1016/j.ijer.2020.101583

Carter, E. W. (2013). Supporting Inclusion and Flourishing in the Religious and Spiritual Lives of People With Intellectual and Developmental Disabilities. Inclusion, 1(1), 64-75. https://doi.org/10.1352/2326-6988-1.1.064

Cihak, D. F., Moore, E. J., Wright, R. E., McMahon, D. D., Gibbons, M. M., \& Smith, C. (2016). Evaluating Augmented Reality to Complete a Chain Task for Elementary Students With Autism. Journal of Special Education Technology, 31(2), 99-108. https://doi.org/10.1177/0162643416651724

Committee on Educational Interventions for Children with Autism. (2001). Educating Children with Autism. In C. Lord \& J. P. McGee (Eds.), Educating Children with Autism. National Academy Press. https://doi.org/10.17226/10017

Drame, E. R., \& Kamphoff, K. (2015). Perceptions of Disability and Access To Inclusive Education in West. Jurnal Internasional Pendidikan Khusus, 29(3), 69-82. http:/ / www.internationaljournalofspecialeducation.com

Fiorenzo, L., \& Barbara, T. (2020). Individual planning starts at school. Tools and practices promoting autonomy and supporting transition to work for adolescents with autism spectrum disorder. Ann Ist Super Sanità, 56(2), 225-229. https://doi.org/10.4415/ANN_20_02_12

Gunarsa, S. D. (2003). Psikologi untuk Keluarga [Psychology for Families]. PT BPK Gunung Mulia. https:/ / opac.perpusnas.go.id

Hakiman, Alwiyah, N., \& Iskandar, B. (2020). Ethical Conduct Towards Students Implied in Surah AlKahf (18:60-82) (A Study of Quraish Shihab's Tafsir AlMisbah). Shahih, 5(2), 1-15. ttps:/ / ejournal.iainsurakarta.ac.id

Hamid, A., Muhammad, H., \& Ullah, I. (2020). Role of Shadow Teacher in the provision of Academic and Social Support for Children with Special Needs at Inclusive Schools. Journal of Inclusive Education, 4(1), 129-144. https://jie.aiou.edu.pk/wpcontent/uploads/2021/01/Paper-9.pdf

Hansen, B. S. (1983). Phenomenology of Religion: A Bridge between the Scholarly Study of Religion and Religious Education. British Journal of Religious Education, 6(1), 14-19. https://doi.org/10.1080/0141620830060104

Hanum, L. (2012). Pembelajaran Pai Bagi Anak Berkebutuhan Khusus [Islamic Religious Education for children with special needs]. Pendidikan Agama Islam, 11(1), 81-89. 
https://doi.org/10.14421/jpai.2014.112-05

Heward, L. W., Alber-Morgan, S. R., \& Konrad, M. (2013). Exceptional learner: An Introduction to Special Education (Eleventh E). The Ohio University. https://www.amazon.com/Exceptional-Children-Introduction-SpecialEducation/dp/0135160421

Iswandia, D. A., Kusmintardjo, \& Yusuf Sobri. (2017). Peran Shadow Teacher dalam Layanan Khusus Kelas Inklusi di SDN Percobaan 1 Kota Malang [The roles of shadow teachers in inclusive classroom at SDN Percobaan 1 Malang City]. Journal UM, 3(1-8), 1689-1699. https://doi.org/10.1017/CBO9781107415324.004

Jauhari, M. N., \& Rafikayati, A. dan R. K. (2018). Keterlibatan Orangtua Dalam Penanganan Anak Berkebutuhan Khusus [The involvement of parents of children with special needs]. Abadimas Adi Buana, 02(1), 55-64. http://jurnal.unipasby.ac.id/index.php/abadimas/article/download/1636/145 $8 /$

Kementerian Agama Republik Indonesia. (2019). KMA 183 Tahun 2019 tentang Kurikulum PAI dan Bahasa Arab [Decree of Minister of Religious Affairs Number 183 of 2019 on the Curriculum of Islamic Religious Education and Arabic]. https:// pustakapendisntt.com/2019

Kistoro, H. C. A., Kartowagiran, B. K., \& Latipah, E. L. (2020). Implementation of Islamic religious learning strategies in children with autism in Indonesia. Specijalna Edukacija i Rehabilitacija, 19(594), 227-246. https://doi.org/10.5937/specedreh1928813

Koh, M.-S., \& Shin, S. (2017). Education of Students with Disabilities in the USA: Is Inclusion the Answer? International Journal of Learning, Teaching and Educational Research, 16(10), 1-17. https:// doi.org/10.26803/ijlter.16.10.1

Kok, N., Chia, H., \& Wong, M. E. (2014). From Mental Retardation to Intellectual Disability: A Proposed Educological Framework for Teaching Students with Intellectual Disabilities in Singapore. Academic Research International, 5(3), 147163.

Kustawan, D. (2013). Manajemen Pendidikan Inklusif [Inclusive Education Management]. Luxima Metro Media. https://opac.perpusnas.go.id

Lal, R., \& Ganesan, K. (2011). Children with Autism Spectrum Disorders: Social Stories and Self Management of Behaviour. British Journal of Educational Research, 1(1), 36-48. http://sciencedomain.org/abstract/213

Leytham, P. A., Nguyen, N., \& Rago, D. (2020). Curriculum Programming in the General Education Setting for Students With Autism Spectrum Disorder. Teaching Exceptional Children, 10(10), 1-10. https:// doi.org/10.1177/0040059920968885

Love, A. M. A., Findley, J. A., Ruble, L. A., \& McGrew, J. H. (2020). Teacher Self-Efficacy for Teaching Students With Autism Spectrum Disorder: Associations with Stress, Teacher Engagement, and Student IEP Outcomes Following COMPASS Consultation. Focus on Autism and Other Developmental Disabilities, 35(1), 47-54. https://doi.org/10.1177/1088357619836767

Maftuhin, \& Fuad, J. (2018). Pembelajaran Pendidikan Agama Islam Pada Anak Berkebutuhan Khusus [Islamic Religious Education for children with special needs]. Journal An-Nafs: Kajian Penelitian Psikologi, 3(1), 76-90. https://doi.org/10.33367/psi.v3i1.502

Matolo, M. F., \& Rambuda, A. M. (2021). Factors impacting the application of an inclusive education policy on screening, identification, assessment, and support of the learners at schools in South Africa. International Journal of Learning, Teaching and Educational Research, 20(9), 207-221. https://doi.org/10.26803/IJLTER.20.9.12 
McDonald, \& Jasmine. (2014). How Parents Deal with the Education of Their Child on the Autism Spectrum The Stories and Research They Don't and Won't Tell You. Sense Publishers. https://doi.org/10.1007/978-94-6209-782-7

Merdan, F., \& Ozcan, D. (2020). The effectiveness of video modelling for teaching daily life skills to children with autism spectrum disorder. Internasional Journal of Learning and Teaching, 12(1), 42-54. https://doi.org/10.1177/108835760001500302

Mian, A. L. (2012). Mental Disability in Medieval Hanafī Legalism. Islamic Studies, 51(3), 247-262. https://doi.org/10.2307/43049909

Miles, M. B., Huberman, M., \& Saldana, J. (2014). Qualitative data analysis: An expanded sourcebook (H. Salmon (ed.); 3rd ed.). SAGE Publication,Inc. https://www.amazon.com/Qualitative-Data-Analysis-MethodsSourcebook/dp/1452257876

Morad, Nasri, Joav, \& Merrick. (2001). Islam and the person with intellectual disability. Jurnal of Religion, Disability \& Helath, 5(2-3), 65-71. doi: 10.1300/J095v05n02_05

National Autistic Society. (2020). Strategies and interventions - TEACCH. https://www.autism.org.uk

Nur'aini, Dewi, D. S. E., \& Hawani, S. (2014). Model Program Pembelajaran Individual Untuk Peserta Didik Dengan Kesulitan Belajar Melalui Pelatihan Terapi Gerak Bagi Shadow Teacher di SD Iklusi [Individual learning program for students with learning difficulties through movement training: A technique for shadow teachers at inclusive elementary school]. (Proceedings of SNaPP2014) Social, Economic and Humanities, 319-326. http:// proceeding.unisba.ac.id

Oktari, W., Harmi, H., \& Wanto, D. (2020). Strategi Guru Dalam Pembelajaran PAI Pada Anak Berkebutuhan Khusus [Instructional strategy of Islamic Religious Education for children with special needs]. Ta'dibuna, 2(2), 13-28. https://doi.org/10.30659/jpai.3.1.13-28

Onwumere, D. D., Cruz, Y. M., Harris, L. I., Malfucci, K. A., Seidman, S., Boone, C., \& Patten, K. (2020). The Impact of an Independence Curriculum on SelfDetermination and Function in Middle School Autistic Students. Journal of Occupational Therapy, Schools, and Early Intervention, 00(00), 1-15. https://doi.org/10.1080/19411243.2020.1799904

Poston, D. J., \& Turnbull, A. P. (2004). Role of spirituality and religion in family quality of life for families of children with disabilities. Education and Training in Developmental Disabilities, 39(2), 95-108. https://www.semanticscholar.org

Puspitaningtyas, \& Pratiwi. (2018). Pendekatan Pembelajaran Anak Autis Dengan Menggunakan Metode Floor Time Di Sekolah Dasar Kec.Situbondo Kabupaten Situbondo [Instructional approaches for children with autism using floor time method in elementary school in Situbondo Regency]. Jurnal Riset Pendidikan Dasar, 1(2), 78-83. https:// doi.org/10.26618/jrpd.v1i2.1564

Raguindin, P. Z. J., \& Ping, L. Y. (2020). Situating “children-supporting-children" platform in the context of the inclusive agenda: A phenomenological Exploration. International Journal of Learning, Teaching and Educational Research, 19(6), 303-322. https:// doi.org/10.26803/IJLTER.19.6.18

Rahman, A., \& Dahlan, A. (2015). Islamic Transformation Centre and the Quadruple Helix Model ( QHM ) Collaboration: Empowering Disabled Students through Inclusive Education. International Journal of Social Science and Humanities Research, 3(4), 556-561. www.researchpublish.com

Rahmawati, A. (2018). Konsep Pembelajaran PAI bagi anak berkebutuhan khusus di Sekolah Inklusi: Studi kasus di SD Semai Jepara. Jurnal Pendidikan Islam, 3(2), 171-183. https://doi.org/10.28918/jei.v3i2.1686 
Rämä, I., Kontu, E., \& Pirttimaa, R. (2020). Special Education without Teaching Assistants? The Development Process for Students with Autism. Journal of Education and Learning, 9(6), 163. https://doi.org/10.5539/jel.v9n6p163

Rasyid, S. (2002). Fikih Islam [Islamic jurisprudence]. Sinar Baru Algensindo.

Republik Indonesia. (2005). Peraturan Pemerintah (PP) tentang Standar Nasional Pendidikan [Government Regulation on National Education Standards]. In Standar Nasional Pendidikan (Issue https:// peraturan.bpk.go.id/Home/Details/49369/pp-no-19-tahun-2005

Republik Indonesia. (2013). Undang-Undang Republik Indonesia NO 20 Tahun 2003 Tentang Sistem Pendidikan Nasional [Act Number 20 of 2003 on National Education System]. https://peraturan.bpk.go.id/Home/Details/43920/uu-no-20-tahun2003

Republik Indonesia. (2014). Peraturan Menteri Pendidikan dan Kebudayaan Republik Indonesia Nomor 104 Tahun 2014 [Regulation of the Minister of Education and Culture of the Republic of Indonesia Number 104 of 2014]. In Pedoman Evaluasi Kurikulum [Guidelines for Curriculum Evaluation]. https://jdih.kemdikbud.go.id/

Richardson-gibbs, Marie, A., \& Klein, D. M. (2012). Making Preschool Inclusion Work: Strategies for Supporting Children, Teachers, and Programs (1st ed.). Paul. H. Brokes Publishing. https://doi.org/https://www.amazon.com/Making-PreschoolInclusion-Work-Strategies/dp/1598572113

Rutherford, M., Baxter, J., Grayson, Z., Johnston, L., \& O'Hare, A. (2020). Visual supports at home and in the community for individuals with autism spectrum disorders: A scoping review. Autism, 24(2), 447-469. https:// doi.org/10.1177/1362361319871756

Sarafino, E. P., \& Smith, T. W. (2011). Health psychology: biopsychosocial interactions (ketujuh). https://doi.org/10.1016/0738-3991(96)00903-2

Schaap-Jonker, H., Sizoo, B., van Schothorst-van Roekel, J., \& Corveleyn, J. (2013). Autism Spectrum Disorders and the Image of God as a Core Aspect of Religiousness. International Journal for the Psychology of Religion, 23(2), 145-160. https:// doi.org/10.1080/10508619.2012.688005

Sha'arani, N. B., \& Tahar, M. M. (2017). Tantrum Behavior Modification for Autistic Student at Secondary School Using Social Stories Technique. Journal of ICSAR, 1(2), 140-144). https://doi.org/10.17977/um005v1i22017p140

Smith, J. A., Flowers, P., \& Larkin, M. (2009). Interpretative phenomenological analysis: Theory, method and research. https://www.amazon.com/InterpretativePhenomenological-Analysis-Theory-Research/dp/1412908345

Sparapani, N., Morgan, L., Reinhardt, V. P., Schatschneider, C., \& Wetherby, A. M. (2016). Evaluation of Classroom Active Engagement in Elementary Students with Autism Spectrum Disorder. Journal of Autism and Developmental Disorders, 46(3), 782-796. https://doi.org/10.1007/s10803-015-2615-2

Spector, J. E. (2011). Sight word instruction for students with autism: An evaluation of the evidence base. Journal of Autism and Developmental Disorders, 41(10), 14111422. https://doi.org/10.1007/s10803-010-1165-x

Sugiarti, R., Ekowati, R., Munawaroh, S. munawaroh, \& Juharyanto. (2019). The Effectiveness of Scaffolding Method to Increase Daily Prayer Ability of Mentally Retarded Student in Muhammadiyah Extraordinary High School. Advances in Social Science, Education and Humanities Research, 285(Icet), 208-211. https://doi.org/10.2991/icet-18.2018.39

Syamsuri, Kaspullah, \& Aslan. (2021). The Understanding Strategy of Worship to Exceptional Children. Edukasi, 9(1), 18-31. https://ejournal.staimtulungagung.ac.id 
Tim Badan Pengembangan dan Pembinaan Bahasa. (2016). Kamus Besar Bahasa Indonesia [The Great Dictionary of the Indonesian]. Balai Pustaka. https://kbbi.web.id/ibadat

Usop, D. S., \& Lilik, K. (2017). Islamic Education For Autism. Anterior Jurnal, 17(1), 1-10. https:// www.researchpublish.com/journal/IJSSHR/Issue-3-July-2017September-2017/0

Van Der Steen, S., Geveke, C. H., Steenbakkers, A. T., \& Steenbeek, H. W. (2020). Teaching students with Autism Spectrum Disorders: What are the needs of educational professionals? Teaching and Teacher Education, 90. https:// doi.org/10.1016/j.tate.2020.103036

Vassallo, T., Dallos, R., \& Mckezie, R. (2020). Parent and Teacher Understandings of the Needs of Autistic Children and the Processes of Communication between the Home and School Contexts. Autism-Open Access, 10(4), 1-10. https://doi.org/10.35248/2165-7890.20.10.262.Copyright

Villa, \& Thausand. (2005). Creating an Inclusive School (2nd ed.). Association for Supervision and Curriculum Development.

Watson, B., \& Thompson, P. (2016). The Eective Teaching of Religious Education (2nd ed.). Routledge. https://www.amazon.com/Effective-Teaching-ReligiousEducation/dp/1138169749

Wright, J. C., Knight, V. F., \& Barton, E. E. (2020). A review of video modeling to teach STEM to students with autism and intellectual disability. Research in Autism Spectrum Disorders, 70, 101476. https:/ / doi.org/10.1016/j.rasd.2019.101476

Zee, M., \& Koomen, H. M. Y. (2016). Teacher Self-Efficacy and Its Effects on Classroom Processes, Student Academic Adjustment, and Teacher Well-Being: A Synthesis of 40 Years of Research. Review of Educational Research, 86(4), 981-1015. https:// doi.org/10.3102/0034654315626801

Zulaikhah, D., Sirojuddin, A., \& Aprilianto, A. (2020). Analisis Pembelajaran Pendidikan Agama Islam kurikulum K13 Bagi Anak berkebutuhan [Analysis of Islamic Religious Education in the Curriculum 2013 (K13) for children with special needs]. Tafkir: Interdiciplinary Journal of Islamic Education, 1(1), 54-71. https://doi.org/10.31538/tijie.v1i1.6

Zulyan, Yolandari, J., Qurniati, A., \& Hasibuan, M. (2020). Studi tentang Individualized Education Program (IEP) Bagi Anak Berkebutuhan Khusus Dalam Pembelajaran PPKN [Study on Individualized Education Program (IEP) for children with special needs in Civic Education learning]. Journal of Education and Instruction, 3(2), 385-393. https://doi.org/https://doi.org/10.31539/joeai.v3i2.1865 